\title{
Does One Stand to Gain by Combining Art with Philosophy? A Study of Fourth-Year College (13/14 Years of Age) Philosophical Writings Produced Within the PreCPhi/Philosophemes Corpus
}

\author{
Hélène Maire ${ }^{1,2}$, Emmanuèle Auriac-Slusarczyk ${ }^{1}$, Bernard Slusarsczyk ${ }^{1}$, Marie-France Daniel $^{3}$ \& \\ Cathy Thebault ${ }^{1}$ \\ 1 Laboratoire Activité Connaissance Transmission Education (EA 4281), Université Clermont Auvergne, \\ Clermont-Ferrand, France \\ ${ }^{2}$ Laboratoire Lorrain de Psychologie et Neurosciences de la Dynamique des Comportements (EA 7489), \\ Université de Lorraine, Nancy, France \\ ${ }^{3}$ Groupe de Recherche sur l'Ethique et l'Education Ethique, Université du Québec à Montréal, Québec, Canada \\ Correspondence: Emmanuèle Auriac-Slusarczyk, Laboratoire Activité Connaissance Transmission Education \\ (EA 4281), Université Clermont Auvergne, Clermont-Ferrand, France.
}

$\begin{array}{ll}\text { Received: March 24, } 2018 & \text { Accepted: April 15, } 2018 \quad \text { Online Published: May 15, } 2018 \\ \text { doi:10.5539/jel.v7n4p1 } & \text { URL: https://doi.org/10.5539/jel.v7n4p1 }\end{array}$

\begin{abstract}
Creative thinking is sometimes neglected by schools. Introducing philosophy in schools represents a commitment to balancing the development of logical and creative thinking, currently exercised only orally. In the present study, the focus is on writing. Firstly, the value of authentic pupil writings is underscored. The pupils and students studied wrote texts for "Adolescence et Société", a magazine produced by researchers. 100 students' works, written by philosophizing students in fourth-year college in France, culled from the PreCPhi/Philosophemes Corpus (1,300 texts collected from 43 classrooms) were studied in order to measure the progress of philosophizing students between a pre-test and a post-test following the introduction of a pedagogical tool that unites Art with Philosophy, Philo \& Carto. Their writing skills were measured according to the following five dimensions: linguistic, philosophical, cognitive, reflective and creative. Performance measures, calculated on group averages and applied to the group's variance between the pre- and the post-tests, were related to each dimension. Linguistic performance (presence of an introduction and conclusion) did not progress, remaining subject to pupils' academic level. Philosophical, cognitive, creative and reflective performance increased significantly, or at least confirmed the trend. Reasoning, metaphors, conceptual differences and discourse ownership increased, while anecdotal examples decreased. These increases were accompanied by an increase in the post-test variance: gaps between the strongest and the weakest performances widened, except in the case of questioning, personal examples and generation of doubt, which were at the core of the effect produced. The study validates the fact that the Art and Philosophy link promises unprecedented educational prospects with regard to the production of early quality philosophical writings. This will require validation with other samplings.
\end{abstract}

Keywords: pedagogy, college, writing, creativity, art, philosophy, development

\section{Introduction}

Our contribution focuses on taking a closer look, or a new look, at the spontaneous or free texts pupils produce in a school context in connection with the development of oral practice within the school (Chabanne \& Bucheton, 2002; David, 2000).

Over the last thirty years, pupils in schools have been trained to produce texts of different types: narrative, argumentative, expository, descriptive, technical, scientific, etc. These texts are often divided into categories, such as writing a recipe, or a poem, so that production of free texts is declining. In parallel, the practice of editing/rewriting texts, systematized in the classroom by the work of researchers who associate these practices with their evaluations (Groupe EVA, Roger, Plane, \& Garcia-Debanc, 2003), although they aim to improve the texts and help the pupils, has produced a form of sterilization of pupils' intellectual possibilities (Lafont-Terranova, 2009; Reuter, 1986), which was indeed observed relatively early on (Mas, Plane, \& Turco, 1994). It takes time to deploy new pedagogical practices in the field. In France, since the 2000s, philosophical sessions in schools (from 
ages 5 to 16) have provided an incentive to return to a type of writing that is free, responsible, unencumbered and spontaneous, such as in the free texts first introduced in schools by Célestin Freinet (Reuter, 2008; Vergnoux, 2001) who revisited the idea of writing for oneself (Lafont-Terranova, 2009).

The multidisciplinary usefulness of collecting oral and written school corpuses in studying the development of writing abilities has been proven, in line with the Corpus Linguistique (Cori \& David, 2008; Cori, David, \& Léon, 2008; Slobin, Sainclair, \& Halliday, in Léon, 2008) and through the works of psycholinguists (Gunnarson-Largy \& Auriac-Slusarczyk, 2013; Slusarczyk \& Auriac-Slusarczyk, 2013). Within this framework, the PreCPhi/Philosophemes (Note 1) Corpus provides information regarding pupils' capacity to write philosophically, as in the development of free, responsible, civic and original thinking that arises from reflection through pupils' understanding of philosophy (Gregory, Haynes, \& Murris, 2017; Lipman, Sharp, \& Oscanyan, 1980).

The present research corresponding to COPHILEC progamm (Note 2) classifies and measures the positive impact of philosophy on the quality of pupils' writings; pupils who, in France, have yet to be specifically taught any philosophy (Note 3). Conducted from a developmental and cognitive psychology study perspective, this research examines a) how oral philosophy sessions help pupils to produce quality philosophical writings, b) how the link between Art and Philosophy ensures actual creative thinking, and c) how an analysis of pupils' authentic writings, to the extent that they are produced as free texts, provides us with the opportunity to further explore the link between the mobilization of creative thinking and the editorial quality of adolescent writings.

\section{The State of Art}

First and foremost, the benefits of philosophical sessions are discussed, then several writing analysis models are reviewed, and finally an a priori definition of a "philosophical text" is suggested.

\subsection{Benefits of Philosophical Sessions}

Philosophy in the classroom takes place within a community of inquiry. It unfolds in five key steps: reading material, preparing a list of questions, engaging in dialogue based on the questions, learning-reinforcement exercises, and inclusion of philosophy in artistic or mobilizing projects (Lipman, 2003, in Gregory et al., 2017). To facilitate the first step, a number of educational short stories were created by Lipman's successors: these alternate narrative with dialogues, featuring true-to-life characters (Daniel, 2002; Lipman et al., 1980; Talbot, 1999). The performance and the benefits of educational tools that introduce philosophy into the classroom in an innovative manner are well established (Gregory et al., 2017): development of dialogical skills (Daniel, Pettier, \& Auriac-Slusarczyk, 2011), mobilization of dialogical critical thinking (Daniel \& Gagnon, 2012, 2013), increased self-esteem, ability to reason, to de-center, implementation of argumentative capacities (Leleux, 2005; Millett \& Tapper, 2012; Topping \& Trickey, 2007) and so on. Although the benefits of philosophical practice are internationally recognized, research within France's colleges (secondary schools) is quite recent. It has been shown that oral philosophical practice produces a homogenization of cognitive abilities by reducing intellectual gaps between philosophizing students (Slusarczyk, Fiema, Auriel, \& Auriac-Slusarczyk, 2015). Weekly practice of philosophy sessions reduces the positive but unequal correlations between students' academic levels (Çokluk-Bökeoğlu, 2008) and their degree of intellectual integrity (Auriac-Slusarczyk, Adami, \& Daniel 2010). A gain of approximately two years in global intellectual maturity in philosophizing students was identified by Lipman (Lipman, 1991/1995; Mortier, in Leleux, 2005), engaging pupils in what Vygotsky refers to as their zone of proximal development (Auriac-Peyronnet \& Daniel, 2005).

\subsubsection{Favoring Free Texts}

The transition from oral expression to writing has been the object of longstanding studies, and the philosophical genre is often associated with the argumentative genre (Means \& Voss, 1996; Neuman, 2003; Rojas-Dummod, Pérez, Vélez, Gomez, \& Mendoza, 2003). However, oral philosophy would be considered a distinct genre (Auguet, 2003).

Various models exist for the study of writing performance. In cognitive psychology, relatively conventional performance measures are shared (Alamargot \& Chanquoy, 2001; Fayol, 1997; Rijlaarsdam, Van den Berg, \& Couzijn, 2005); however, the relevance of these indicators in the developmental field remains debatable (Gaonach \& Fijalkov, 1998; Gunnarson-Largy \& Auriac-Slusarczyk, 2013; Slusarczyk, 2010). The conventional idea of a distinction between novices and experts is called into question by the free texts' effectiveness. The benefits of providing the freedom to generate innovative ideas, without a pre-established plan, have long been recognized (Elbow, 1973; Glynn, Britton, Muth, \& Dogan, 1982; Kellog, 1996, in Hayes, 2006; Murray, 1978). This is not to suggest that there are no benefits when constraints are positive (Haught-Tromp, 2016), nor that writing guidelines have no impact on writing quality (Cappeau \& Roubaud, 2005). Moreover, an abundant literature has pointed out 
that studying writings/oral expressions according to textual genres (Dolz \& Schneuwly, 1998) or discourse types (Bronckart, Bain, Schneuwly, Davaud, \& Pasquier, 1985) is a good starting point. With regard to the generation of ideas, some authors link this to the concept of creativity; if it is generally agreed that pupils' knowledge underpins the generation of ideas (MacArthur, Graham, \& Fitzgerald, 2006), Hayes (1996) and Galbraith (1999) insist on pupils' potential for creativity-transformation of ideas, a potential which, operating at different moments in the process (planning, writing, editing) would influence writing quality. Generation of ideas might thus be influenced by philosophical practice, it being generally accepted that philosophy increases conceptual productivity, calculated as the number of ideas and described as facilitating dialogical networking between ideas (Auriac, 2007). Also, the pupil's draft version (preliminary text) is an ideal space within which to understand the writing process and its functional dynamic within a developmental perspective in schools (Fabre, 1990; Fabre-Cols, 2000) and universities (Fénoglio \& Chanquoy, 2007; Piolat \& Barbier, 2007).

\subsubsection{An A Priori Definition of "Philosophical Writing"}

To the extent that teaching philosophy in France only takes place in the final year of lycée (17/18 years of age), dissertation might be considered an expert model for standard philosophical writing. However, since these students are versed in philosophy, this textual genre (dissertation) cannot be used. This is why a minimal theoretical definition of what a philosophical writing genre could be is suggested, outside of the dissertation model. Future investigations will validate or invalidate some aspects considered here. For our part, seven criteria have been $a$ priori identified to define the genre, including reflective, cognitive and philosophical dimensions (Auriac-Slusarczyk, Slusarczyk, \& Thebault, 2016; Auriac-Slusarczyk, Slusarczyk, \& Thebault, submitted; Auriac-Slusarczyk, Slusarczyk, Thebault, \& Pironom, 2018).

1) Philosophical Writing (PW) akin to dissertation would include invention, making it less typically argumentative and more of an organization of ideas within the text creation space.

2) To compose a PW, within a theme (difference between men and women, madness), one would proceed with the knowledge at hand and present the state of a given issue from different angles: examining, comparing and distinguishing them. A singular and impressionist part (what one thinks, perceives, glimpses) would accompany the activation of mutually-shared knowledge. One can know the same things yet present them differently. This singularity should not be regarded as anecdotal; it should instead be attributed to standing by one's point of view.

3) In PW, several concepts would draw the main lines of action, reflection, doubt or perspectives; these concepts can also directly represent such alternatives. This being the case, one must exercise care with regard to tracing strict boundaries between vocabulary, ideas and concepts.

4) The act of composing a PW activates an original production that is not reproducible. Indeed, there is an extremely creative (personalizing the essay, news story, letter, pamphlet, tale, etc.) and extremely logical act (universality of the text in which the voice(s) of other philosophers are expressed) associated with philosophy.

5) PW does not necessarily have a recipient: writing can be for oneself (essay), or to engage in society (pamphlet, news story).

6) PW potentially opens onto contradictory discussion: taken as a voice that expresses itself, it functions as respondent or reaction, and although not necessarily concluded, it provides the reader or the author with food for thought.

7) Finally, as with other texts, PW is contextual and marked by a time period; in this era of internet, transgenic technology and generic medication, one does not evoke the same knowledge as during the horse-and-buggy or cholera days; paradoxically, some main lines and questionings remain identical, transcending time: "What does a human search for in caring for himself?" If contextual character does not specifically define PW, it depends on the generation of knowledge that places the text within a historical problem area situated for the benefit of an explicitly universal scope.

This definition identifies a few generic ingredients that have the advantage of dissociating the philosophical script from strictly argumentative models. In our view, argumentation, distinguished from narration, serves to identify and promote the creativity (see Ucus, 2017), required by the act of philosophizing (Dewey, 1980/1984; see also Alexander, 1987; Jackson, 1998), Dewey being, in this area among others, an inspirer of Lipman (Daniel, 1992/1997). Since this is a theoretical and a priori definition, the seven criteria of PW are converted to study variables in a perspective of cognitive and developmental psychology (Maire \& Auriac-Slusarczyk, 2017). Five dimensions contribute to defining quality philosophical writing (linguistic, cognitive, philosophical, creative and reflective dimensions; see below). 


\subsection{Creative/Divergent Thinking and Philosophy}

The benefit of the innovative and tested Philo \& Carto educational tool lies in the balanced development between logical and creative thinking. What creative thinking offers is examined, particularly with regard to psychology, and focus on the production of metaphors.

\subsubsection{Creative Thinking and the Key Role of Metaphors}

Different ways could support creation of creative and innovative education (Seechaliao, 2017). Lipman gave equal consideration to creative and logical thinking, two distinct but crucial processes in the development of reasoning (Lipman, 1991). Social confrontation with peers reveals know-how that mobilizes both the logical and creative processes. When psychologists study creative thinking, they refer to it as divergent thinking (Besançon, Barbot, \& Lubart, 2011; Sternberg, 1999; Villalba, 2008). Considered by Binet (Binet \& Henri, 1895), studied by Guilford (1950), tested by Torrance (1966) and subsequently by Lubart in France (Besançon \& Badot, 2011), creative or divergent thinking has been the subject of ongoing, although minor, research by cognitivists. Some associate it with personality (Gostoli, Cerini, Piolanti, \& Rafanelli, 2017; Kim \& Choi, 2017; Lennartsson, Horwitz, Theorell, \& Ullén, 2017), while others insist on tying it to the way analogical reasoning, central in humans, works (Hofstadter \& Sander, 2013). Production of metaphors is important to divergent thinking, and globally useful in education (Causarano, 2015).

In the Aristotelian sense: "[t] he metaphor is a transfer of meaning (epiphora) that consists in giving the thing a name that belongs to something else; the transference being either from genus to species, or from species to genus, or from species to species, on the grounds of analogy (Aristotle, translation by Hardy, 1932/2002). The metaphoric path thus plays a key role in cognition (Haught, 2014), and student have facilities to create metaphor in linguistic context to traduce their perceptions (see Cansever \& Alsan, 2016). Linking it to philosophical reasoning, Lipman specified that: "Metaphorical thinking is thus a synthesis of incompatibles that yields, like binocularity, a far greater depth of vision by the mere act of juxtaposition. It is thinking that, from the perspective of either of the categories it bridges over, is bound to seem false, just as thinking among the disciplines often seems false by the standards that exist within the disciplines." (Lipman, 1991/1995, p. 239). Eco, however, explains the common mistrust associated with the use of metaphors: he who uses metaphors would be a "liar" (Eco, 1984, p. 142). Yet metaphors overcome the stumbling block of sterile parallels, where the image is strained. Mobilizing metaphors engages the thought process. It has a cognitive value that "introduces us to something which it is not literally applicable" (Blay, 2007, p. 516). A study conducted on the production of philosophical writing in elementary schools shows that girls are more likely than boys to produce metaphors (Auriac-Slusarczyk et al., 2018), whereas no such effect was detected in the study of lycée students (Auriac-Slusarczyk et al., 2016; Auriac-Slusarczyk et al., submitted).

\subsubsection{Philo \& Carto: An Educational Tool that Unites Art and Philosophy}

To render "analogy its due" (Hofstadter \& Sander, 2013, p. 9), choosing artistic supports provides pupils with an incentive to mobilize their creativity during philosophy sessions. Artwork builds a useful bridge toward philosophy (Dalsuet, 2015), because "the artist's vision, both analytic and panoramic, renders the parts and the whole perceptible simultaneously. Through inspection and introspection, art reveals to man what he has yet to discover in himself" (Hayman, 1961, p. 9). According to the scientist Changeux, artwork would be a "source" of humanity (Changeux, in Marmion, 2017). This is why a tool to associate philosophical and artistic approaches was conceived. Philosophical discussion is directly summoned by a collective presentation of works of art (Leckey, 2017; Thebault, 2015). Through successive stages, as in Lipman's original model (see above), by bringing Art and Philosophy together during the educational process, graphic language and philosophical speech are articulated (Carreras, 2017; Murris, 1992). As such, this tool covers what others, centered solely on reasoning, have seldom explored directly (Saint-Dizier de Almeida \& Auriac-Slusarczyk, 2016; Tozzi, 2002). To illustrate, based on a work of art such as René Magritte's Submissive Reader, pupils are asked to examine the artistic medium, and to identify a few salient pictorial elements (about ten) before collecting philosophical questions (e.g.: "Why is reading scary?", "Can we be subjugated to culture?"). Then the pupils discuss in a philosophical manner for an hour before drawing out ten concepts (main ideas) from the philosophical exchange. Subsequently, they associate the ten pictorial elements previously identified with the ten concepts that stemmed from the discussion, debating the relevance of the associations and creating metaphoric formulas to illustrate the link between Art and Philosophy. The lively metaphors created ("the nose of impulse"; "the lip of pleasure"; "the locks of choices") are then integrated into a final collective fresco (Figure 1, below), capturing what was said in a metaphoric cartography. 

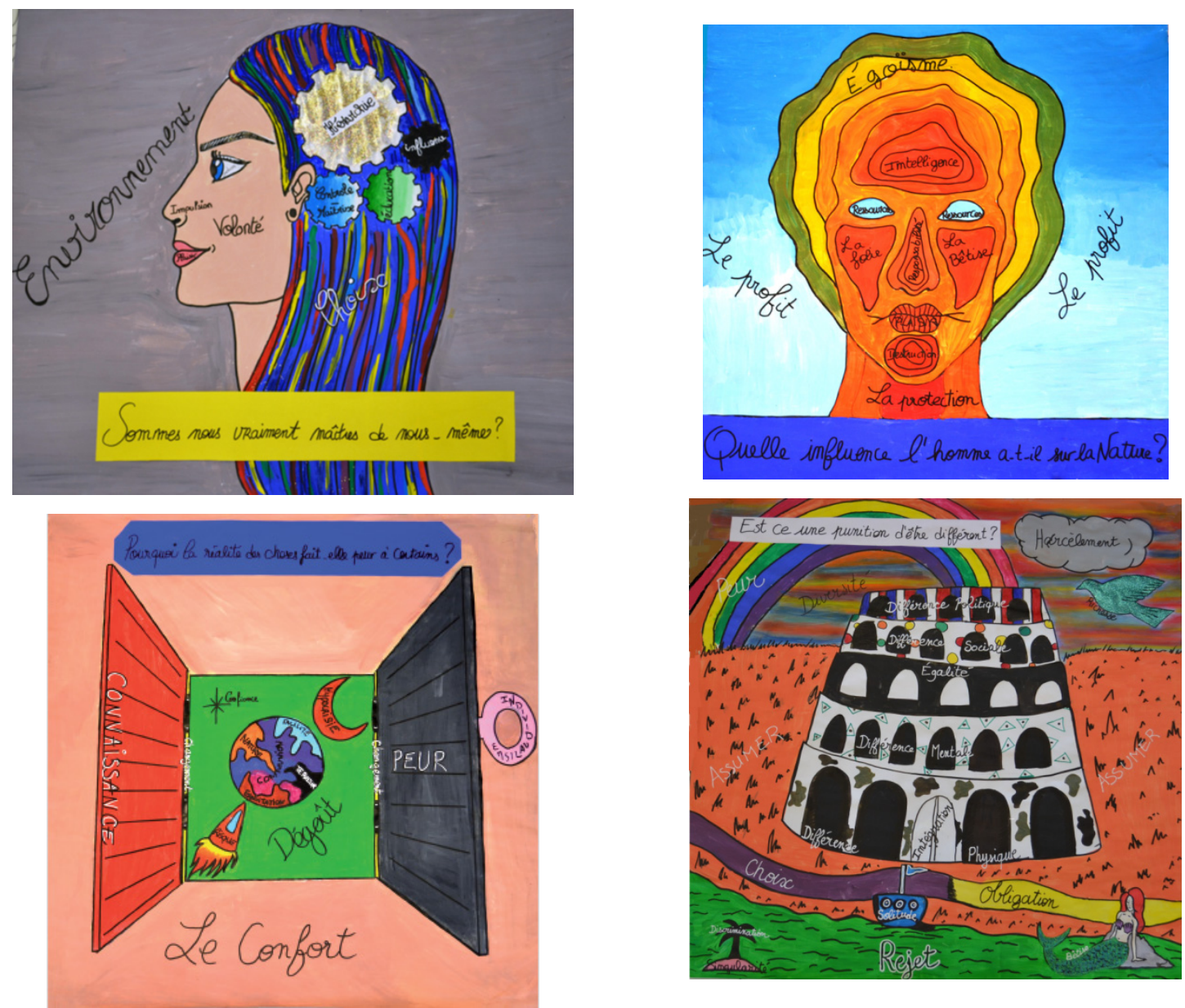

Figure 1. Collective fresco originating from Philo \& Carto session work, Collège de Champeix, France, COPHILEC project, based on Magritte's Submissive Reader, on The Tower of Babel by Pieter Bruegel and on The Geographer by Johannes Vermeer

The thought processes and accomplishments of pupils from fourth-year college (third-year secondary school) were collected in a publication (Slusarczyk, 2017).

\section{General Method}

Following are the principles that guided the collection of all texts used to study the link between Art and Philosophy as they pertain to the introduction of the Philo \& Carto educational tool, in which the experimental protocol followed by fourth-year college (third-year secondary school) students is set. Students aged 13 and 14 years wrote texts according to standardized instructions developed in the COPHILEC project. Half the group had benefited from two years of weekly sessions of philosophical awareness, in sixth and fifth year college (first and second year of secondary school). Studied here is the progress of the philosophizing fourth-year college students who were offered the Philo \& Carto educational tool that links Art and Philosophy (Auriac-Slusarczyk et al., 2016, Auriac-Slusarczyk et al., 2018; Thebault, 2015). The other half of the group, comprised of regular students, benefited from a minimal introduction to the works of art presented to philosophizing students.

\subsection{PreCPhi/Philosophemes Corpus Collection Principles}

The objective of the progressively developed PreCPhi/Philosophemes Corpus (see Table 1) is to emphasize the interest in and the impact of the Art and Philosophy educational tool as tested both with secondary school students (11 to 14 years: fourth; sixth; fifth year college) and in elementary school classrooms (8 to 12 years: CE2-CM2) (Note 4). The goal is to enable studying of the writing process based on the pupils' graphical and linguistic indicators (Andersen, Birkelund, Leblay, \& Auriac-Slusarczyk, 2010; Fénoglio \& Boucheron-Pétillon, 2002). Although in cognitive psychology progress is described in stages (e.g., Piaget, 1936/1977), some developmental levels would benefit from a clinical examination. Thus, Lipman states: "I thought here is a dimension of childhood 
power and creativity that is completely missed by the people who think that children begin with intellectual weakness and then gradually mount up to higher and higher echelons of strength and understanding" (Lipman, 1991, in Gregory et al., 2017). Archiving of manuscript texts ensures access to authentic pupils productions and highlights their value.

The capacities of all regular, philosophizing and control group students were measured according to four waves of compiled student works (June, 2016, September 2016, October 2016 and February/March 2017; see Table 1). Pupils in each group (control, philosophizing, regular) were identified according to their academic level (grades in French or general level during the year, sometimes detailing the level by term).

Table 1. Table of all four PreCPhi/Philosophemes corpus compilations [COPHILEC project]

\begin{tabular}{|c|c|c|c|c|}
\hline \begin{tabular}{|l} 
Number of classrooms \\
\end{tabular} & Number of texts & School level & Classroom type & School sector \\
\hline \multirow{15}{*}{$\begin{array}{l}15 \text { CLASSROOMS } \\
\text { June } 2016\end{array}$} & 16 & 5 th & regular & REP+ \\
\hline & 20 & 5 th & regular & REP+ \\
\hline & 13 & 4 th & regular & REP+ \\
\hline & 21 & 4 th & regular & $\mathrm{REP}+$ \\
\hline & 21 & 4 th & regular & RURB \\
\hline & 26 & 4 th & regular & RURB \\
\hline & 25 & 4 th & regular & URBA \\
\hline & 23 & 4 th & regular & URBA \\
\hline & 29 & 5 th & regular & RURB \\
\hline & 26 & 5 th & regular & RURB \\
\hline & 28 & 4 th & regular & RURB \\
\hline & 22 & 4 th & regular & RURB \\
\hline & 21 & 5 th & regular & $\mathrm{REP}+$ \\
\hline & 11 & 4th & regular & REP+ \\
\hline & 15 & 4 th & regular & $\mathrm{REP}+$ \\
\hline \multirow{10}{*}{$\begin{array}{l}10 \text { CLASSROOMS } \\
\text { September } 2016\end{array}$} & 28 & 4 th & control & RURB \\
\hline & 24 & 4 th & control & RURB \\
\hline & 25 & 4 th & control & RURB \\
\hline & 21 & 4 th & philosophizing & RURB \\
\hline & 22 & 4 th & philosophizing & RURB \\
\hline & 21 & 4 th & philosophizing & RURB \\
\hline & 20 & 4 th & philosophizing & RURB \\
\hline & 22 & CE2 CM1 & philosophizing & $\mathrm{REP}+$ \\
\hline & 20 & CM2 & philosophizing & $\mathrm{REP}+$ \\
\hline & 27 & CM1 & philosophizing & URB \\
\hline \multirow{8}{*}{$\begin{array}{l}8 \text { CLASSROOMS } \\
\text { October } 2016\end{array}$} & 25 & CM1-CM2 & regular & URB \\
\hline & 27 & $\mathrm{CM} 2$ & regular & URB \\
\hline & 23 & CM1 & regular & RURB \\
\hline & 20 & $\mathrm{CM} 2$ & regular & RURB \\
\hline & 20 & 4th & regular & RURB \\
\hline & 26 & 4 th & regular & RURB \\
\hline & 29 & 4 th & regular & RURB \\
\hline & 27 & 4th & regular & RURB \\
\hline \multirow{10}{*}{$\begin{array}{l}10 \text { CLASSROOMS } \\
\text { February/March } 2017\end{array}$} & 22 & CE2 CM1 & philosophizing & $\mathrm{REP}+$ \\
\hline & 20 & CM2 & philosophizing & REP+ \\
\hline & 27 & CM1 & philosophizing & URB \\
\hline & 28 & 4 th & control & RURB \\
\hline & 24 & 4 th & control & RURB \\
\hline & 25 & 4 th & control & RURB \\
\hline & 21 & 4 th & philosophizing & RURB \\
\hline & 22 & 4 th & philosophizing & RURB \\
\hline & 21 & 4 th & philosophizing & RURB \\
\hline & 20 & 4 th & philosophizing & RURB \\
\hline
\end{tabular}

Note. Grey boxes represent the philosophizing students studied in this paper. Pupils came from various sectors: REP + refers to sectors of priority education that correspond to disadvantaged and usually multicultural neighbourhoods. UR means urban. RUB stands for semi-rural and semi-urban. 
In the "regular" classrooms, no educational approach was used. In the philosophizing classrooms, a protocol linking Art and Philosophy engaged students in philosophizing regularly based on eight selected works of art. In the control classrooms, a protocol incorporated the same eight works of art from the experimental protocol to ensure a comparison. Pupils came from various sectors (priority education, urban, semi-rural and semi-urban).

\subsection{PreCPhi/Philosophemes: Works of Art Selected and Standardized Material}

The advantage of the PreCPhi/Philosophemes Corpus lies in its standardized material. Given that the planning process (draft: ideas jotted down in a pre-text) is easier in secondary school than in elementary school (Fénoglio \& Chanquoy, 2007; Pouit \& Golder, 1997), students and pupils could plan their ideas in a pre-text (Auriac \& Favart, 2007). Elementary school pupils were assigned three written pages while secondary school students were assigned five pages (see Figure 2).

\subsubsection{Material}

The media used to initiate the writing process were carefully examined in continuation and consideration of Lipman's work, and focused on the artistic dimension. The introduction of artistic media was tested gradually according to the Corpus' progressive compilation.

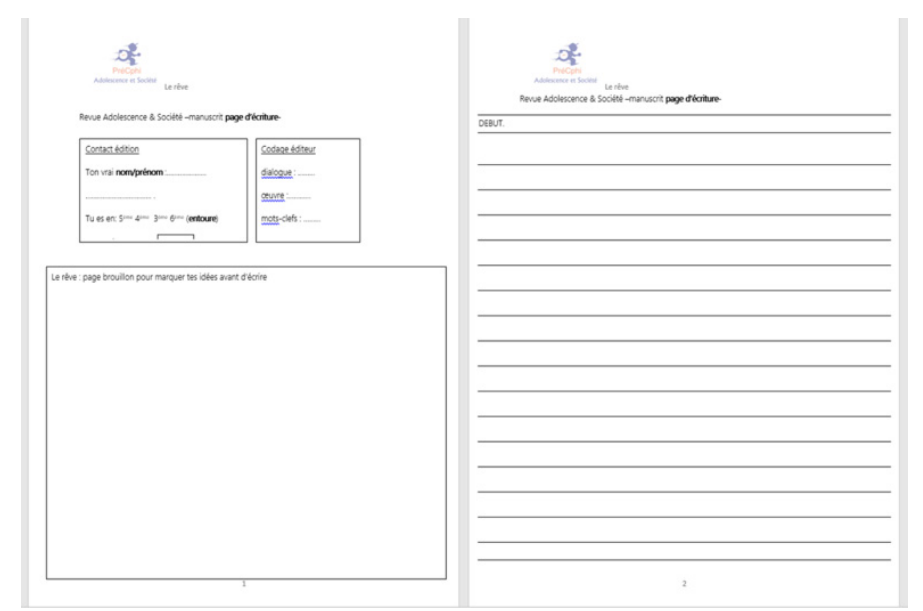

Figure 2. Standardized writing handouts: pre-text and first page of text

Students participated by producing a written composition of their choosing. They were told that they would be writing for the magazine "Adolescence et Sociéte", soon to be launched.

\subsubsection{Artwork Media Selected to Study Creative/Divergent Thinking}

The various media, tested in Wave 1 (June 2016) confirmed that artwork reproductions provided the most satisfactory conditions (Auriac-Slusarczyk et al., submitted). Three suggested guidelines to pre-experiment with the media were used: a) dialogue, b) key word, or c) image (Note 5). For Waves 1, 2 and 3 (June, September and October 2016), reproductions of works (Note 6) by Etienne Cournault were used (Cournault, 2015), since Cournault is a contemporary painter famous for favoring divergence as he guides the viewer toward a dream world; he evokes "Picasso, Dali or André Breton"; his works are often composite, colourful, suggestive and "recall those of Cubists, Surrealists and metaphysicits" (Briand-Vaugeois, Chanteloup, Chevallier, Dauvert, De Lemos, \& Cougnaud 2016). The work Chasseur d'étoiles, by Richard Texier, another contemporary painter, was chosen for the post-test with philosophizing students in Wave 4 (February/March 2017). 


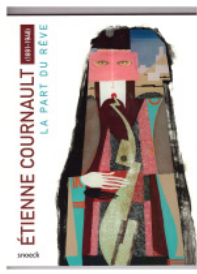

La part du rêve Waves 1, 2 and 4

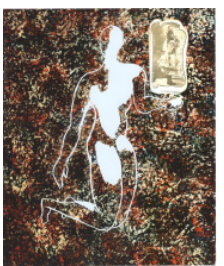

Poupée parisienne Wave 3

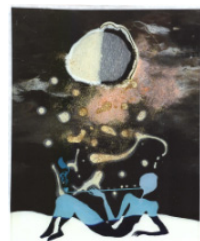

Fumeur de bleu Wave 3

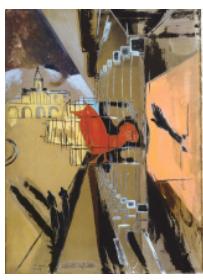

La liberté

Wave 3

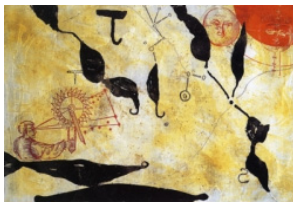

Chasseur d'étoiles

Wave 4

Figure 3. Visuals of selected artwork

A few student productions (see Figures 4 and 5) serve to illustrate the content and wealth of the PreCPhi/Philosophemes Corpus collected in the 43 classrooms.

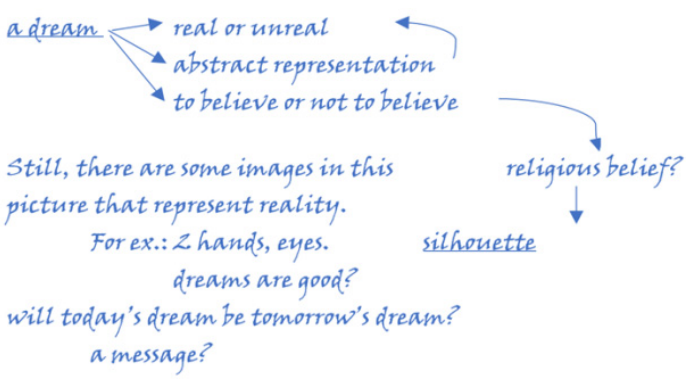

Figure 4. Pre-text (left) and corresponding text (right) from a fourth-year college student (philosophizing group, Wave 2) (artwork: La part du rêve, Etienne Cournault)

The first impression I had of this picture was that it looked like a silhouette. More exactly like a veiled woman. It's because we only see her eyes and her hand, and none of the other images show parts of the human body.

The images in the picture are in an "abstract" style, and some of them seem similar.

The fact that there are lots of images, could that be to depict dreams? Real or unreal dreams?

Everybody has dreams and are free to believe in them or not.

Maybe this image wants to leave a message? Believe your dreams? Not believe your dreams?

This silhouette made me think of a veiled lady, this message could speak about equality of belief.

On the other hand, this might speak about the problems there are right now, and by the date (1891-1948), shows us that these problems are not just today's. There are so-called "premonitory" dreams, maybe this picture is one and wants to show us what happened.

Every dream can be different, with several feelings, several ideas, several contexts. They will never be the same.

A dream can be real in our eyes and unreal in other peoples'.

Will today's dream come true tomorrow?

We can read lots and lots of messages in this picture. Everyone can think whatever they like about the dream.

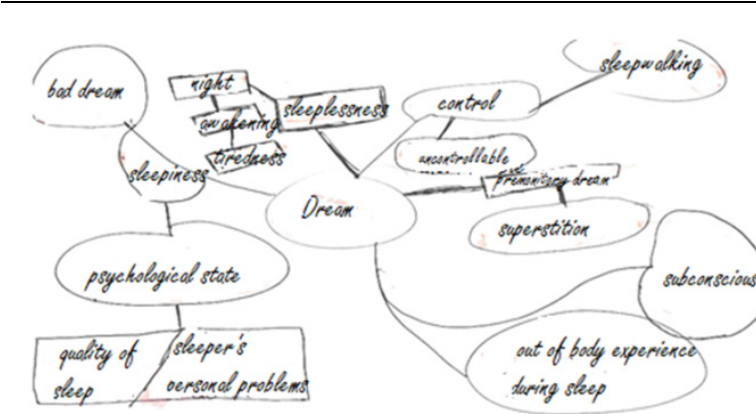

Lots of things can happen in one night. Some things are positive like dreams where we see ourselves happy or when we think of something joyful.

Other sadder and frightening things happen like insomnia that can bring on nightmares or leave us feeling very tired.

If some people are superstitious (or not), they can believe (or not) in premonitory dreams.

We must know that how well someone sleeps depends on their personal difficulties and their psychological state.

During "normal" sleep when the person has controlled their emotions, their dreams are generally good and controlled.

On the other hand, some dreams are uncontrollable (dreams or emotions). It's the person's unconscious that then comes into play to make them leave their body in their sleep. Then when we wake up we feel odd, but we don't realize what's happened.

Another fact like sleepwalking can also come into it. It's what I call dangerous dreaming.

That's what dreaming is for me.

Figure 5. Pre-text (left) and corresponding text (right) from a fourth-year college student (philosophizing group, Wave 4) (artwork: Chasseur d'étoiles, Richard Texier) 
In these pre-texts, students demonstrated well-organized thinking. They developed a methodology (spidergrams or mind maps) usually associated with the development level of university students (Piolat \& Barbier, 2007).

\section{Experimentation with Philosophizing Fourth-Year-College Students}

Subjects were those from Waves 2 (pre-test) and 4 (post-test).

\subsection{Participant Selection}

These findings concern only philosophizing students from Waves 2 and 4; studies regarding the first Waves have already been published (Auriac-Slusarczyk, Slusarczyk, \& Thebault, submitted). It should be noted that these were fourth-year college students who had previously practiced philosophical discussions in sixth and fifth-year college (in the first and second year of secondary school), and were thus relatively skilled in oral philosophy.

Of the initial sampling of 84 students, 168 texts were produced ( 84 in pre-test, compiled in October 2016, and 84 in post-test, compiled in February 2017), 60 texts had to be discarded because at least one of the texts from these 30 students was not useable: 25 students produced a personal-experience narrative (usually a dream they had), four turned in an empty paper, four turned in a text in which the writing, once scanned, was illegible, and one produced a fictional text inspired by the work of art that was provided as a starting point. Therefore our findings are based on 50 students (29 girls, average age 13.1 years, standard deviation $(S D)=0.31$ ) and their 100 texts: 50 pre-test and 50 post-test, considered useable both to study the philosophical content in the pre-test and the degree of progress between the pre- and post- tests.

These 100 texts were evaluated using 17 psycholinguistic variables, which were selected as linguistic, philosophical, cognitive, creative and reflective performance indicators (see Auriac-Slusarczyk et al., 2016; Auriac-Slusarczyk et al., 2018; Maire \& Auriac-Slusarczyk, 2017; and see below).

\subsection{Writing Task}

After compiling the Wave 2 texts (pre-tests), philosophizing classrooms were introduced to the Philo \& Carto educational tool within interdisciplinary learning spaces (I.L.S.) co-facilitated by a Literature or History and Geography professor and an Arts professor. Students discussed and completed their collective frescoes based on eight works of art (see Table 2) selected by their teachers from among some twenty proposed by the researchers. In the pre-test, their composition was based on La part du rêve, a work of art by painter Étienne Cournault, used by the previous Waves; in the post-test, Chasseur d'étoiles, the work of contemporary painter Richard Texier, was used (see Figure 3).

Table 2. Artwork selected for experimentation in fourth-year college classrooms

\begin{tabular}{|c|c|c|c|c|c|c|c|}
\hline Painting & Painting & Painting & Drawing & Photography & Painting & Painting & Sculpture \\
\hline $\begin{array}{l}\text { The Tower } \\
\text { of Babel }\end{array}$ & $\begin{array}{l}\text { The } \\
\text { Geographer }\end{array}$ & $\begin{array}{l}\text { Submissive } \\
\text { Reader }\end{array}$ & Vive l'amour & Passage & $\begin{array}{l}\text { Anthropo- } \\
\text { morphic } \\
\text { Landscape }\end{array}$ & $\begin{array}{l}\text { Psyche } \\
\text { Opening the } \\
\text { Golden Box }\end{array}$ & $\begin{array}{ll}\text { Storm King } \\
\text { Wall }\end{array}$ \\
\hline $\begin{array}{l}\text { by Pieter } \\
\text { Bruegel, } \\
\text { oil on } \\
\text { panel } \\
\text { (1563). }\end{array}$ & $\begin{array}{l}\text { by Johannes } \\
\text { Vermeer, oil } \\
\text { on canvas } \\
(1668-69) \text {. }\end{array}$ & $\begin{array}{l}\text { by René } \\
\text { Magritte, oil } \\
\text { on canvas } \\
(1926) \text {. }\end{array}$ & $\begin{array}{l}\text { by Niki de Saint } \\
\text { Phalle } \\
\text { (1930-2002), felt } \\
\text { and gouache on } \\
\text { bristol (1990) }\end{array}$ & $\begin{array}{l}\text { by Robert and } \\
\text { Shana Parke } \\
\text { Harisson } \\
(1993-94)\end{array}$ & $\begin{array}{l}\text { by Joos de } \\
\text { Momper, oil } \\
\text { on panel } \\
(1610) \text {. }\end{array}$ & $\begin{array}{l}\text { by John } \\
\text { William } \\
\text { Waterhouse, } \\
\text { oil on canvas } \\
\text { (1903) }\end{array}$ & $\begin{array}{l}\text { by Andy } \\
\text { Goldsworthy, } \\
\text { fieldstones in } \\
\text { situ } \\
(1997-1998)\end{array}$ \\
\hline
\end{tabular}

Note. Images of these works of art can be downloaded online.

The same instructions were given to the students for the pre-test and the post-test: "A new magazine will come out in newsstands and on the internet. It concerns adolescents, what they think about, their concerns, the subjects that interest them. You are asked to write for this new magazine: Adolescence et Société. The theme is: A dream. Look at the following reproduction for inspiration. It is a work painted by Full Name (of the artist), a contemporary artist. Then jot down a few notes (space is provided). Finally, write your manuscript directly on the publisher's sheet." Students are prompted to write again on the same theme (A dream) with the following explanation on the first page of the handout provided: "The publisher needs a second text. You will again be writing for the Adolescence et Sociéte magazine". Although a time limit is not given, it must not exceed the 50 minutes of the class, including distribution of handouts and instructions.

\subsection{Developmental Hypotheses}

Our first assumption is that the Philo \& Carto educational tool would have a positive impact on the progress of philosophizing students in terms of writing quality. Particularly, this educational tool could help students to evolve 
with regard to philosophical and creative performance (H1: main hypothesis). Then we would verify whether the progress expected in the post-test was consistent with the tendency toward homogenization previously identified (Slusarczyk et al., 2015); the variance (between strong and weak students) should diminish between the pre- and the post-test (H2). Finally, in a more exploratory manner, with reference to the Çokluk-Bökeoğlu study (2008), we would establish that difference in academic levels has a lesser incidence on the students' pre-test and post-test performances (H3).

\subsection{Presentation of Chosen Study Variables}

\subsubsection{Five Spheres of Abilities (H1, H2)}

As previously mentioned and based on the work of Auriac-Slusarczyk et al. (2018), five performance categories were targeted: linguistic, philosophical, cognitive, creative and reflective.

The linguistic performance indicators were: a) the number of statements, b) the presence or absence of an introduction and c) the presence or absence of a conclusion.

The philosophical performance indicators were the ratios of the number of a) assumptions, b) hypotheses and c) questionings to the total number of statements, the ratio of the number of d) "non-personal" examples (i.e.: general in nature) to the total number of examples given by the student, and e) the score on the reasoning scale $(0=$ no reasoning; 1=local reasoning; 2="active" reasoning adequately inserted in the text; and $3=$ organizational reasoning, which structures the text's architecture).

The cognitive performance indicators were the ratio of a) the number of concepts (meaning key ideas) to the total number of statements, and $b)$ the score on distinction between concepts $(0=$ no distinction; $1=$ local distinction; $2=$ planning "step by step" distinction that coincides with a beginner's working method; $3=$ organizational distinction, which structures the text's architecture and coincides with an expert's working method).

The creative performance indicators were the ratio of a) the number of metaphors to the total number of statements, and $b$ ) the score on the divergence scale $(0=$ no divergence; $1=$ local divergence; $2=$ regular divergence; and $3=$ final divergence; Auriac-Slusarczyk et al., 2018).

Finally, the reflective performance indicators were the ratio of a) the number of "personal" examples to the total number of examples provided by the student; and b) the number of first-person singular pronouns such as " $I$ ", "me", "my", etc. (these two indicators jointly evaluate self-focused attention), as well as the ratios of c) the number of first-person singular pronouns that indicate ownership of the discourse, d) words "of opinion", evaluative and/or of implication, and e) words expressing doubt, uncertainty or nuance, to the total number of statements.

Gender (a) and academic level (b) (calculated according to average grade in French in the first term and on the overall average for the year) were also controlled.

\subsubsection{Introducing Academic Level as a Variable (H3) and Controlling Gender Effect}

A previous work having shown that regular oral philosophical practice served to weaken the correlation between intellectual integrity and academic level by favoring a homogenization of the class (Slusarczyk et al., 2015), it became relevant to investigate whether and how the previously-described pre-test and post-test performances were related to the students' academic level. Academic level was assessed using two indicators: a global indicator (overall yearly average) and a more specific indicator (first term average grade in French). We verified any possible progress $(\mathrm{H} 1)$ tied to reduced variance in the post-test (H3), since a class can progress by increasing or reducing performance differences between students.

With regard to the gender effect, following previous studies, we looked into whether the gender effect present in elementary schools (Auriac-Slusarczyk et al., 2018) disappeared in secondary school (Auriac-Slusarczyk et al., 2016; Auriac-Slusarczyk et al., submitted).

\subsubsection{Statistical Tests}

Sample distributions on different dependant variables not being normal, nonparametric tests were conducted to compare performance between pre- and post- tests. These statistical analyses were applied to the means in order to verify any possible gain tied to philosophical practice in the various dimensions investigated (H1). These analyses were also applied to the variances, to confirm score dispersion (H2). For dichotomous variables (presence/absence of introduction and conclusion), Fisher's exact test (Note 7) was applied. With regard to other variables, continuous or ordinal, Wilcoxon tests for paired samples were conducted. 
Subsequently, Wilcoxon tests for paired samples and the Spearman correlation test (rho $\rho$ ) were conducted to test the impact of academic level on performances (H3); Mann-Whitney tests were used to test the possible impact of gender.

\section{Results}

Descriptive then inferential statistics were presented, addressing the hypotheses in order: validation of $\mathrm{H} 1, \mathrm{H} 2$ then H3.

\subsection{Evolution of Performance Between Pre- and Post-Tests}

Descriptive statistics of mean scores and their variances appear in Table 3 below.

Table 3. Means and variances of textual indicators that reflect linguistic, philosophical, cognitive, creative and reflective performance of fourth-year college students who philosophized using the Philo \& Carto educational tool, in pre- and post- tests

\begin{tabular}{|c|c|c|c|c|c|}
\hline \multirow[t]{2}{*}{ Performance } & \multirow[t]{2}{*}{ Indicators } & \multicolumn{2}{|l|}{ Means } & \multicolumn{2}{|c|}{ Variances } \\
\hline & & pre-test & post-test & pre-test & post-test \\
\hline \multirow[t]{3}{*}{ Linguistic } & Statements & 21.140 & 17.260 & 296.680 & 137.912 \\
\hline & Introduction & 0.180 & 0.460 & 0.148 & 0.248 \\
\hline & Conclusion & 0.220 & 0.300 & 0.172 & 0.210 \\
\hline \multirow[t]{5}{*}{ Philosophical } & Assumptions & 0.323 & 0.386 & 0.036 & 0.038 \\
\hline & Hypotheses & 0.054 & 0.089 & 0.005 & 0.016 \\
\hline & Non-personal examples (i.e.: of a general character) & 0.382 & 0.641 & 0.010 & 0.023 \\
\hline & Reasoning (arguments) & 0.033 & 0.051 & 0.002 & 0.002 \\
\hline & Questionings & 0.025 & 0.028 & 0.006 & 0.004 \\
\hline \multirow[t]{2}{*}{ Cognitive } & Distinctions & 0.095 & 0.147 & 0.006 & 0.023 \\
\hline & Concepts & 1.067 & 1.540 & 0.295 & 0.844 \\
\hline \multirow[t]{2}{*}{ Creative } & Divergence & 0.031 & 0.037 & 0.003 & 0.003 \\
\hline & Metaphors & 0.027 & 0.056 & 0.003 & 0.008 \\
\hline \multirow[t]{5}{*}{ Reflective } & First-person singular pronouns & 0.463 & 0.271 & 0.402 & 0.094 \\
\hline & Personal examples (anecdotes) & 0.618 & 0.359 & 0.016 & 0.008 \\
\hline & $\begin{array}{l}\text { First-person singular pronouns that indicate ownership of the } \\
\text { statement }\end{array}$ & 0.085 & 0.132 & 0.009 & 0.018 \\
\hline & Opinion/evaluative and/or implication words & 0.040 & 0.054 & 0.003 & 0.008 \\
\hline & Nuance, doubt, uncertainty & 0.087 & 0.117 & 0.015 & 0.022 \\
\hline
\end{tabular}

\subsection{Improvements in Philosophical, Cognitive, Creative and Reflective Mean Performance with Partial Homogenization of the Class}

The Wilcoxon and Fisher tests applied to means and variances underscored the positive effects of the Philo \& Carto tool in four of the five targeted performance areas. Progress concerned the philosophical, cognitive, creative and reflective dimensions (H1 validated). Only the linguistic dimension was not positively affected. Gaps between pupils with regard to self-focused attention, size of text and questioning decreased, in line with Hypothesis 2 . However, $\mathrm{H} 2$ was not validated with regard to other indicators (presence of introduction, conclusion, concepts, distinctions, metaphors, ownership of discourse) and gaps between students increased (H2 invalidated).

\subsubsection{Linguistic Performance: Uninfluenced by the Tool and Increase in Differences}

Linguistic performance was uninfluenced by the Philo \& Carto educational tool: the mean number of introductions and conclusions remained stable between the pre- and post- tests (in Fisher's exact tests, respectively: $p=.27$ and $p=.71, n s)$. By contrast, from pre- to post- test their respective dispersions increased significantly with regard to introductions (Fisher's exact test: $p=.03$ ) and tendentially with regard to conclusions (Fisher's exact test: $p=.06$ ), showing a widening of the gaps between students. A tendential decrease was observed in the size of the texts as measured by the total number of statements (Wilcoxon test: $p=.09$ ). The dispersion and size of texts was significantly reduced, from Var $=269.680$ to $V a r=137.912$ (see Table 3; Wilcoxon test: $p=.02$ ), indicating homogenization of the class in line with Hypothesis 2.

\subsubsection{Philosophical Performance: Progress and Homogenization of Scores for Questionings}

Pedagogical practice tendentially improved the philosophical quality of texts produced: students scored higher on the reasoning scale (Wilcoxon test: $p=.06$ ), provided more non-personal and general examples (for example: "in 
dreams we can do anything, like fly or own up to someone") (Wilcoxon test: $p=.07$ ), and developed more hypotheses (Wilcoxon test: $p=.09$ ). The quantity of assumptions (for example: "dreaming is often linked to the stars", "a dream is an imaginary world" (Note 8), in reference to the artwork medium Chasseur d'étoiles) and questionings (for example: "is dreaming magic?", "is it good to dream?") did not differ significantly between pre- and post- tests (Wilcoxon test, respectively: $p=.11$ and $p=.55, n s$ ). Dispersion remained stable for assumptions, non-personal examples and on the reasoning scale score (Wilcoxon test: $p \mathrm{~s}>.05, n s$ ). By contrast, dispersion was reduced for questionings (validation $\mathrm{H} 2$ : homogenization).

\subsubsection{Cognitive Performance: Significant Progress but Increase in Dispersion}

Important progress was observed between October and February, with a significant increase in the number of concepts generated (for example: "nightmare", "play", "reality"...) (Wilcoxon test: $p=.02$ ) and in the score on the distinction between concepts (for example: "dreaming is what we do when we are asleep, but we can also dream when we are awake", "we can't not dream, but we can't decide what we dream about") (Wilcoxon test: $p=.02$ ). Score dispersion between the pre- and post-tests increased significantly, both for scores on the distinction between concepts, from Var $=0.006$ to Var $=0.023$ (see Table 3; Wilcoxon test: $p=.0001$ ), and for the production of concepts (Wilcoxon test: $p=.02$ ). In other words, performance improved (H1 validated), but at the same time, gaps between students widened ( $\mathrm{H} 2$ invalidated).

\subsubsection{Creative Performance: Increase in Metaphors}

Creative performance showed contrasting progress between the pre-test and the post-test. The proportion of metaphors doubled, from $M=0.027$ to $M=0.056$ (see Table 1; Wilcoxon test: $p=.02$ ), under the influence of the tool (H1 validated). It is interesting to note that the metaphors produced were often based on the artwork media and explicitly linked art with philosophy (for example, based on Chasseur d'étoiles: "the dark patches in the picture could be the dark hidden side: death, suffering, sadness", "with time what we expect vanishes but dreams stay forever, as though life was filled with balloons and one by one the balloons burst but [...] not this red balloon that holds all our dreams" (Note 8)). Sample dispersion significantly increased (Wilcoxon test: $p=.0001$ ), indicating widening gaps between students who produced metaphors. On the other hand, the divergence scale score remained stable, as did its dispersion (Wilcoxon test: $p \mathrm{~s}>.15, n s$ ).

5.2.5 Reflective Performance: Increase in Doubts, Decrease in Self-Focused Attention, but Increase in Discourse Ownership Differences

Reflective performance evolved interestingly. Students moved toward de-centering of self (i.e., weaker self-focused attention) between the pre- and post-tests: they reduced their use of first-person pronouns ("I", "me", etc.) (Wilcoxon test: $p=.07$ ) and personal examples (i.e., anecdotal or life stories: "It's already happened to me after I've gone fishing that I dreamt I was a fish and that I got caught and eaten") ( $p=.07)$. This de-centering was accompanied by a homogenization of performance with a decrease in dispersion: first-person singular pronoun variance decreased fourfold (from Var $=0.402$ to $\operatorname{Var}=.0 .094$, see Table 3; Wilcoxon test: $p=.005$ ) and the use of personal examples decreased twofold (from Var $=0.016$ to Var $=.0 .008$, see Table 3; Wilcoxon test: $p=.0001$ ). In parallel, students expressed significantly more doubts/nuances (Wilcoxon test: $p=.02$ ), with no significant change in variance with regard to this indicator (Wilcoxon test: $p=.31, n s$ ). Pronouns in discourse ownership ("I believe", "I think"), tendentially more numerous in the post-test than in the pre-test (Wilcoxon test: $p=.06$ ), were used more disparately among the students (significant increase in variance: Wilcoxon test: $p=.003$ ). Finally, the use of opinion/evaluative and/or implication words remained stable (Wilcoxon test: $p=.49, n s$ ), and distribution became more heterogeneous in the post-test compared to the pre-test (significant increase in variance: Wilcoxon test: $p=.02$ ).

\subsection{Explanation of Academic Level and Gender Performance}

Among the variables retained, linguistic and creative performance were particularly highlighted, which are sensitive to sample dispersion and generate classroom heterogeneity in the post-test (invalidation of $\mathrm{H} 2$ ).

\subsubsection{Linguistic Performance Significantly Correlated with Academic Level}

According to the Wilcoxon or Spearman (rho $\rho$ ) tests, academic level explains performance. Positive correlations were tied to the number of statements, to average grades in French (in the pre-test: $\rho=0.58, p=.0001$; in the post-test: $\rho=0.30, p=.04$ ), and to overall averages (in pre-test: $\rho=0.45, p=.002$; in post-test: $\rho=0.51, p=.0001$ ). Academic level also explains the presence of an introduction and a conclusion in the texts (Wilcoxon test: all $p \mathrm{~s}=.0001$ ). Thus, students' linguistic performance remained linked to their academic level. Practice did not decrease this dependence ( $\mathrm{H} 3$ not validated). 


\subsubsection{Absence of Gender Effect on Production of Metaphors}

The Mann-Whitney test indicated no gender effect on the production of metaphors, neither in the pre-test (Mann-Whitney test: $p=.33, n s$ ) nor in the post-test (Mann-Whitney test: $p=.43, n s$ ) indicating an absence of differences between girls and boys with regard to this variable (H3 not validated). Thus secondary-school girls (unlike girls in elementary school) did not appear to be more creative than boys at the same level, as had been observed in previous findings (Auriac-Slusarczyk et al., submitted).

\section{Conclusion}

This research project aimed to verify that standardizing a collection of handwritten texts on a free-text theme (e.g.: "A dream") to study the impact of the Philo \& Carto educational tool in college would contribute to a better understanding of the incremental effects of using Art in Philosophy sessions. Students successfully apprehended the writing task; the writings produced were interesting. In the study of 100 texts of philosophizing fourth-year college students, the relevance of the variables studied in previous studies in determining the philosophical content of student writings prior to any explicit teaching of philosophy was confirmed (Auriac-Slusarczyk et al., 2018; Maire \& Auriac-Slusarczyk, 2017), although some limits will be imposed with regard to better classifying creative thinking (see below).

With regard to the impact of the tool, fourth-year college students participated effectively in writing quality texts with philosophical content, and the classrooms progressed homogeneously: students steadily produced questionings, introduced elements of doubt or nuance in their writings, reduced the number of anecdotal examples in their writings, and used evaluative terms to refine their statements. This finding is highly significant in that it demonstrates the impact of oral philosophy sessions on the written productions of secondary-school students. This can be considered the central core of the ability to philosophize in written form at that age. Nevertheless, it is important to note an eventual exhaustion effect (re-test effect, composition on an identical theme) since students produced shorter texts in February compared to October; however, this shortening did not reduce the stability of the writings' philosophical content, nor students' progress between the pre- and post-tests (see below).

Student progress was significant over all targeted dimensions except for the linguistic: in that case, the students' linguistic performance was determined by their academic level (presence/absence of an introduction and a conclusion, length of text). The practice of philosophy did not influence the quality of writing at this level or narrow the gaps between the strongest and the weakest students.

Students showed progress with regard to their creative, cognitive, philosophical and reflective abilities, although it should be noted that, under the impetus of the educational tool, the strongest students showed greater progress than the weakest; the dispersion of the variance increasing between the pre- and the post-tests for various indicators. More in-depth analyses differentiating student profiles according to academic level will be needed to see whether the strength of this relationship is the same for academically strong and weak students. At the classroom level, the Philo \& Carto educational tool tested had a positive impact on all students with regard to production of metaphors, reasoning and formulation of hypotheses. This result is interesting in that it proves that the Philo \& Carto tool favored both creative aspects (metaphors) and philosophical progress (reasoning, hypotheses). Only the lack of harmony in the results for the two indicators that reflect the development of creative thinking (metaphors increased and divergence diminished between the pre- and the post- tests) raised questions and could be considered as a limitation of our study (see below).

With regard to metaphors, such an effect was not noted, and this study on Waves 2 and 4 confirms the previously findings from Wave 1 (Auriac-Slusarczyk et al., submitted). Complementary studies could serve to verify from what age exactly (between 11 and 13 years) this gender effect, in which girls are more apt at producing metaphors, disappears: the transition to college (at 12 years of age) could enable boys to compensate for a local gap at this level.

Finally, our study indicates that the contribution of handwritten texts and the open character of the data collected (PreCPhi/Philosophemes Corpus) promise to renew decisive studies in education. If philosophy is a teaching discipline (at age 17 in France), an introduction to philosophical reasoning and to setting down this reasoning in writing could occur sooner in schools (as early as age 9). Furthermore, the Humanities and Social Sciences community would benefit from a study of these first philosophical writings. While avoiding the transformation of philosophical awareness into a new subject matter in the program, which would likely once again widen the gaps between the strongest and the weakest students, the PreCPhi/Philosophemes Corpus contains a number of useful indications which were difficult to take into consideration here; for example, the quality of pre-test texts, which will be the subject of future publications (in progress). Although the future benefits that researchers may reap from the PreCPhi/Philosophemes Corpus, to the extent that it is made available to the community on a dedicated 
platform, is undetermined, it may be useful in studying other dimensions (spelling and grammar skills, graphics quality, etc.). The PreCPhi/Philosophemes Corpus could also be subjected to secondary transcriptions (re-transcribed from handwritten texts into searchable text files) to facilitate automated computer searches. It is hoped that researchers will recognize the authenticity of the manuscripts for validating additional hypotheses, or clinically detailing certain texts, and for examining other aspects not covered in this study.

\section{Limitations of the Study}

Given that this study examined only the progress of philosophizing students, a comparative study with students from the control classrooms remains to be completed. The effect attributed to the tool was here combined with a developmental effect. As there was a six-month interval in development, it seems reasonable to suppose that the tool had the greater impact. A complementary compilation is in progress, since the control groups' texts from Waves 2 and 4 incidentally include very little philosophical content, which has for the time being prevented comparisons.

Also, new study variables that focus on creativity, here reduced to two indicators that do not evolve in the same direction (analogies/metaphors, divergences), would be desirable. Further investigations are needed to know whether the characterization of our divergence indicator is correct, or whether the educational tool lacks effect. Since the definition of divergence is in theory tied to both originality and usefulness with respect to context (Vivalba, 2008), it becomes difficult to identify elements of divergence in the writings. Double-judge identification regarding divergence would be helpful. Moreover, measuring divergence on a scale may not be sufficiently sensitive. We might prefer a continuous measure in which one point is coded each time an indication of divergence is identified; this could improve the study and increase our control over score variability (intra and inter).

\section{References}

Alamargot, D., \& Chanquoy, L. (2001). Through the Models of Writing, Studies in Writing (Vol. 9). Dordrecht, Boston, London: Kluwer Academic Publishers. https://doi.org/10.1007/978-94-010-0804-4

Alexander, T. (1987). John Dewey's theory of Art, Experience and Nature. Albany, NY: State University of New York Press.

Andersen, L. A., Birkelund, M., Leblay, C., \& Auriac-Slusarczyk, E. (2010). Acquisition et enseignement en production écrite. Synergies Pays Scandinaves, 5, Denmark: Gerflint.

Aristotle. Poétique (1932/2002), translation by J. Hardy. Paris: Les Belles Lettres.

Auguet, G. (2003). La discussion à visée philosophique aux cycles 2 et 3: un genre nouveau en voie d'institution? (Unpublished doctoral dissertation). Montpellier: Université Montpellier 3.

Auriac, E. (2007). Effet de discussions à visée philosophique sur le processus de génération d'idées. Enfance, 4, 356-370. https://doi.org/10.3917/enf.594.0356

Auriac, E., \& Favart, M. (2007). Passage d'un avant texte au texte dans des écrits scolaires de type argumentatif. Langue Française, 115(3), 69-83. https://doi.org/10.3917/lf.155.0069

Auriac-Peyronnet, E., \& Daniel, M. F. (2005). Impact of regular philosophical discussion on argumentative skills: Reflection about education in primary schools. In G. Rijlaarsdam (Ed.), Studies in Writing (Vol. 14, pp. 291-304). Dordrecht: Kluwer Academic Publishers. https://doi.org/10.1007/978-1-4020-2739-0_20

Auriac-Slusarczyk, E., \& Blasco-Dulbecco, M. (2013). Quand les enfants philosophent. Analyses plurielles du corpus Philosophèmes. Cahier du L.R.L., 5. Clermont Ferrand: Presses Universitaires Blaise Pascal.

Auriac-Slusarczyk, E., \& Colletta, J. M. (2015). Les ateliers de philosophie: une pensée collective en acte. Clermont Ferrand: Presses Universitaires Blaise Pascal.

Auriac-Slusarczyk, E., Adami, J., \& Daniel, M. F. (2011). Tester les prédispositions à l'esprit critique au primaire. Psychologie et Education, 1, 55-80.

Auriac-Slusarczyk, E., Foulquier, M. H., Baptiste, L., \& Slusarczyk, B. (2012). C'est pas moi! Récits écrits d'une narration travaillée collectivement à l'oral au CP. Paper presented at the Colloque International NIL2012, Narration, intervention et littératie: Développement de la narration orale, procédure d'intervention et compréhension de la lecture, France.

Auriac-Slusarczyk, E., Lebas-Fraczak, L., Blasco, M., Daniel, M. F., Colletta J. M., Simon, J. P., ... Henrion, J. (2012). Philosophèmes. Paper presented at the Congrès national du réseau des MSH, Quelles sciences 
humaines et sociales pour le $21^{\text {ème }}$ siècle? Caen, France. Retrieved from http://www.msh-reseau.fr/IMG/pdf/poster_philosophemes.pdf

Auriac-Slusarczyk, E., Slusarczyk, B., \& Thebault, C. (2016, October). La constitution d'un corpus d'écrits scolaires utile aux SHS, Premiers écrits philosophiques. Paper presented at the Colloque international Enseignement et apprentissage de l'écriture de la maternelle à l'université et dans les formations tout au long de la vie, Bordeaux, France.

Auriac-Slusarczyk, E., Slusarczyk, B., \& Thebault, C. (submitted). Pensée divergence et écriture: Expérimentation sur les premiers écrits de type philosophique en classes de $5^{\text {ème }}$ et $4^{\text {ème }}$ collège. Psychologie Française.

Auriac-Slusarczyk, E., Slusarczyk, B., Thebault, C., \& Pironom, J. (2018). Premiers écrits philosophiques. Productivité conceptuelle et créativité rédactionnelle du CE2 au CM2. Bulletin de Psychologie.

Barth, B. M. (1987). L'apprentissage de l'abstraction. Paris: Retz.

Barth, B. M. (2008). De la pratique à la théorie: Apprendre à construire son savoir. In C. Leleux (Ed.), La philosophie pour enfants. Le modèle de Matthew Lipman en discussion. Brussels: De Boeck Université.

Barth, B. M. (2013). Élève chercheur, enseignant médiateur. Paris, Montreal: Retz/Chenelière Éducation. https://doi.org/10.14375/NP.9782725631585

Besançon, M., \& Badot, B. (2011). EPoC Évaluation du potential créatif de Lubart et al. Paris: Editions Hogrefe.

Besançon, M., Barbot, B., \& Lubart, T. (2011). Évolution de l'évaluation de la créativité chez l'enfant de Binet à nos jours. Recherche et Education, 5, 215-226. Retrieved from http://journals.openedition.org/rechercheseducations/840

Binet, A., \& Henri, V. (1895). La psychologie individuelle. L'Année Psychologique, 2, $415-465$. https://doi.org/10.3406/psy.1895.1541

Blay, M. (2007). Article Métaphore, Dictionnaire des concepts philosophiques. Paris: Larousse, Editions du CNRS.

Briand-Vaugeois, F., Chanteloup, C., Chevallier, A., Dauvert, C., De Lemos, A., \& Cougnaud, J. (2016). Compte-rendu de l'exposition visitée par les A1 en janvier-février 2016 au Musée des Beaux-Arts de Nantes (Chapelle de l'Oratoire)—La Divergence guidée par l'univers onirique. Retrieved from http://lettres.lecolededesign.com/2016/05/08/etienne-cournault-la-part-du-reve/

Bronckart, J. P., Bain, D., Schneuwly, B., Davaud, C., \& Pasquier, A. (1985). Le fonctionnement des discours: Un modèle psychologique et une méthode d'analyse. Neuchâtel: Delachaux \& Niestlé.

Cansever, B. A., \& Alsan, N. (2016). “Teacher” from the children's perspective: A study by metaphors. Journal of Education and Learning, 5(4).

Cappeau, P., \& Roubaud, M. N. (2005). Enseigner les outils de la langue avec les textes d'enfants. Paris: Bordas.

Carreras, G. (2017). Philographique. Paris: Tana Editions.

Causarano, A. (2015). Metaphors of literacy: Dialogues in inclusive settings. Journal of Education and Learning, 4(1). https://doi.org/10.5539/jel.v4n1p41

Chabanne, J. C., \& Bucheton, D. (2002). Parler et écrire pour penser, apprendre et se construire. Paris: Presses Universitaires de France. https://doi.org/10.3917/puf.chaba.2002.01

Çokluk-Bökeoğlu, Ö. (2008). Testing factor structure of California Measure of Mental Motivation Scale. World Applied Sciences Journal, 4(1), 94-99.

Cori, M., \& David, S. (2008). Les corpus fondent-ils une nouvelle linguistique?. Langages, 3, $111-129$. https://doi.org/10.3917/lang.171.0111

Cori, M., David, S., \& Léon, J. (2008). Construction des faits en linguistique: La place des corpus, Langage, 171, Paris: Larousse.

Cournault, E. (2015). La part du rêve. Gand: Editions Snoek, Nancy/Nantes: Musée des Beaux Arts.

Dalsuet, A. (2015). Art \& Philosophie. Paris: Editions Palette.

Daniel, M. F. (1992/1997). La philosophie et les enfants, Les modèles de Lipman et de Dewey. Montreal: Logiques \& Brussels: Eds. DeBoeck \& Belin.

Daniel, M. F. (2002). Les contes d'Audrey-Anne. Quebec City: Le Loup de Gouttière. 
Daniel, M. F., \& Gagnon, M. (2012). Pupils' age and philosophical praxis: Two factors that influence the development of critical thinking in children. Childhood and Philosophy, 8(15), 105-130.

Daniel, M. F., \& Gagnon, M. (2013). Dialogical critical thinking in children. Developmental process. In E. G. Carayannis (Ed.). Encyclopedia of Creativity, Intervention, Innovation and Entrepreneurship (pp. 530-537). New-York: Springer Science + Business Media.

Daniel, M. F., Pettier, J. C., \& Auriac, E. (2011). The incidence of philosophy on discursive and language competencies of pupils aged four years. Creative Education, 2(3), $296-304$. https://doi.org/10.4236/ce.2011.23041

David, J. (2000). Etudier les textes d'enfants: Revue de travaux. In C. Fabre-Cols (Ed.), Apprendre à lire des textes d'enfants (pp. 274-285). Brussels: Deboeck \& Bouculot.

Dewey, J. (1980/1984). Art as experience. New York: Berkley Publishing Group.

Dolz, J., \& Schneuwly, B. (1998). Pour un enseignement de l'oral. Initiation aux genres formels à l'école. Paris: ESF.

Eco, U. (1984). Métaphore et sémiosis, In Sémiotique et philosophie du langage (pp. 139-189). Paris: Presses Universitaires de France.

Fabre, C. (1990). Les brouillons d'écoliers ou l'entrée dans l'écriture. Grenoble: Ceditel.

Fabre-Cols, C. (2000). Apprendre à lire des textes d'enfants. Brussels: deBoeck \& Bouculot.

Fayol, M. (1997). Des idées au texte. Psychologie cognitive de la production verbale, orale et écrite. Paris: Presses Universitaires de France. https://doi.org/10.3917/puf.fayol.1997.01

Fénoglio, I., \& Boucheron-Pétillon, S. (2002). Processus d'écriture et marques linguistique. Langages, 147.

Fénoglio, I., \& Chanquoy, L. (2007). Avant le texte: Les traces de l'élaboration textuelle. Langue Française, 155.

Galbraith, D. (1999). Writing as a knowledge constituting process. In M. Torrance \& D. Galbraith (Eds.), Studies in Writing. Knowing what to write: conceptual processes in text production (Vol. 4, pp. 139-160., Amsterdam: Amsterdam University Press.

Gaonach, D., \& Fijalkov, J. (1998). Notes critiques, débat autour d'un livre: Michel Fayol, Des idées au texte Psychologie cognitive de la production verbale, orale et écrite. Revue Française de Pédagogie, 125(1), 147-150.

Gostoli, S., Cerini, V., Piolanti, A., \& Rafanelli, C. (2017). Creativity, bipolar disorder vulnerability and psychological well-being: A preliminary study. Creativity Research Journal, 29, 63-70. https://doi.org/10.1080/10400419.2017.1263511

Gregory, M. R., Haynes J., \& Murris K. (2017). The Routledge International Handbook of Philosophy for Children. London \& New York: Routledge Taylor Francis Group.

Guilford, J. P. (1950). Creativity. American Psychologist, 5, 444-454. https://doi.org/10.1037/h0063487

Gunnarsson-Lary, C., \& Auriac-Slusarczyk, E. (2013). Ecriture et réécriture chez les élèves. Un seul corpus, divers genres discursifs et méthodologies d'analyse. Paris: Academia-Bruylant.

Haught, C. (2014). Spain is not Greece: How metaphors are understood. Journal of Psycholinguistic Research, 43, 351-356. https://doi.org/10.1007/s10936-013-9258-2

Haught-Tromp, C. (2016). Facilitating creative thinking in the 21 st century: When constraints help. In D. Ambrose \& R. J. Sternberg (Eds.), Creative Intelligence in the 21st Century: Grappling with Enormous Problems and Huge Opportunities (pp. 107-117). Rotterdam: The Netherlands: Sense Publishers. https://doi.org/10.1007/978-94-6300-506-7_7

Haught-Tromp, C. (2016). The green eggs and ham hypothesis. How constraints facilitate creativity. Psychology of Aesthetics, Creativity and the Arts, 11(1), 10-17. https://doi.org/10.1037/aca0000061

Hayes J. R. (1996). A new framework for understanding cognition and affect in writing. In C. M. Levy \& S. Ransdell (Eds.), The Science of writing: Theories, methods, individual differences and applications (pp. 1-27). Mahwah, NJ: Lawrence Erlbaum Associates.

Hayes, J. R. (2006). New directions in Writing Theory, In C. A. MacArthur, S. Graham \& J. Fitzgerald (Eds.). Handbook of Writing (pp. 28-40). New York, London: The Guilford Press. 
Hayman D', A. (1961). L'art dans la vie de l'Homme. Le Courrier de l'UNESCO, No Spécial L'Art et la Science, XIVI 1961(7/8), 7-24.

Hofstadter, D., \& Sander, E. (2013). L'analogie au cœur de la pensée. Paris: Odile Jacob.

Jackson, P. (1985). John Dewey and the lessons of art. New Haven, CT: Yale University Press.

Kant, E. (1781). Critique de la raison pure. translated by Tremesaygues \& Pacaud. Paris: Presses Universitaires de France.

Kim, K., \& Choi, S. B. (2017). Influences of creative personality and working environment on the research productivity of business school faculty. Creative Research Journal, 29, 10-20. https://doi.org/10.1080/10400419.2016.1239900

Lafont-Terranova, M. (2009). Se construire, à l'école, comme sujet écrivant: L'apport des ateliers d'écriture. Namur: Presses universitaire de Namur.

Leckey, M. (2017). Guernica comes to school. Art, philosophy and life. In M. R. Gregory, J. Haynes, \& K. Murris (Eds.), The Routledge International Handbook of Philosophy for Children (pp. 137-144). London \& New York: Routledge Taylor Francis Group.

Leleux, C. (2005). La philosophie pour enfants. Le modèle de Matthew Lipman en discussion. Brussels: De Boeck \& Larcier.

Lennartsson, A. K., Horwitz, E. B., Theorell, T., \& Ullén, F. (2017). Creative artistic achievement is related to lower levels of alexithymia. Creative Research Journal, 29, 29-36. https://doi.org/10.1080/10400419.2017.1263507

Léon, J. (2008). Aux sources de la «Corpus Linguistics»: Firth et la London School. In M. Cori, S. David \& J. Léon (Eds.), Construction des faits en linguistique: la place des corpus, Langage, 171, 12-33. https://doi.org/10.3917/lang.171.0012

Lipman, M. (1991). Thinking in Education, translation by N. Decostre, À l'école de la pensée. Brussels: DeBoeck Université.

Lipman, M., Sharp, A. M., \& Oscanyan, F. S. (1980). Philosophy in the classroom. Philadelphia PA: Temple University Press.

MacArthur, C. A., Graham, S., \& Fitzgerald, J. (2006). Handbook of Writing. New York, London: The Guilford Press.

Maire, H., \& Auriac-Slusarczyk, E. (2017, December). De l'oral aux écrits philosophiques. Comparaison de classes philosophant versus tout venant. Paper presented at the Séminaire d'automne, Conditions et manifestations de la pensée réflexive dans les discussions à visée philosophique, Grenoble, France.

Marmion, J. F. (2017). L'art est la source de l'humanité. Rencontre avec Jean Pierre Changeux. Sciences Humaines, 289, 24-27.

Mas, M., Plane, S., \& Turco, G. (1994). Construire des compétences en révision/réécriture au cycle 3 de l'école primaire. Repères, 10, 67-81.

Means, M., \& Voss, J. F. (1996). Who reasons well? Two studies of informal reasoning among students of different grade, ability, and knowledge levels. Cognition and Instruction, 14, 139-178. https://doi.org/10.1207/s1532690xci1402_1

Millett, S., \& Tapper, A. (2012). Benefits of collaborative philosophical inquiry in schools. Educational Philosophy and Theory, 44(5), 546-567. https://doi.org/10.1111/j.1469-5812.2010.00727.x

Murris, K. (1992). Teaching philosophy with picturebooks. Infonet Publications, Ltd.

Neuman, Y. (2003). Go ahead, prove that God does not exist! On high school students' ability to deal with $\begin{array}{llll}\text { fallacious arguments. Learning and } & \text { 367-380. }\end{array}$ https://doi.org/10.1016/S0959-4752(02)00011-7

Piaget, J. (1936/1977). La naissance de l'intelligence chez l'enfant. Neufchâtel, Switzerland: Delachaux et Niestlé.

Piolat, A., \& Barbier, M. L. (2007). De l'écriture elliptique estudiantine: Analyse descriptive de prises de notes et de brouillons. Langue Française, 155, 84-100.

Plantin, C. (2011). Analogie et métaphore argumentatives. A contrario, 2(16), 110-130. 
Pouit, D., \& Golder, C. (1997). Il ne suffit pas d'avoir des idées pour défendre un point de vue. La récupération des idées peut-elle faciliter la production écrite d'une argumentation chez les enfants de 11 à 17 ans. Revue de Psychologie de l'Education, 3, 33-52.

Reuter, Y. (1986). L'amélioration de texte. Études de communication, 7, 75-90. https://doi.org/10.4000/edc.3249

Reuter, Y. (2008). Une école Freinet. Fonctionnements et effets d'une pédagogie alternative en milieu populaire. Paris: L'Harmattan.

Rijlaarsdam, G., Van den Berg, H., \& Couzijn, M. (2005). Effective Learning and Teaching of Writing. New York: Kluwer Academic Publishers. https://doi.org/10.1007/978-1-4020-2739-0

Roger, C., Plane, L., \& Garcia-Debanc, C. (2003). Objectif écrire: évaluer les écrits à l'école primaire. Montpellier: CRDP Languedoc-Roussillon, Paris: Sceren.

Rojas-Dummond, A., Pérez, V., Vélez, M., Gomez, L., \& Mendoza, A. (2003). Talking for reasoning among Mexican primary school children. Learning and Instruction, 13(6), 653-670. https://doi.org/10.1016/S0959-4752(03)00003-3

Saint-Dizier de Almeida, V., \& Auriac-Slusarczyk, E. (2016). Les ateliers-philo en contexte scolaire, Recherche en Education, 24. Nantes: Publication du CREN.

Seechaliao, T. (2017). Instructional strategies to support creativity and innovation in education. Journal of Education and Learning, 6(4), 201-208. https://doi.org/10.5539/jel.v6n4p201

Slusarczyk, B. (2010). Approcher la qualité textuelle des écrits scolaires: le corpus grenouille à l'essai d'un jugement d'expert. Synergies Pays Scandinaves, 5, 97-110.

Slusarczyk, B. (2017). Philosoph'arts. Cartographie philosophique à l'usage de collégiens. Clermont Ferrand: Édition Un deux quatre.

Slusarczyk, B., \& Auriac-Slusarczyk, E. (2013). L'intérêt de la comparaison oral-écrit pour comprendre et accompagner le développement rédactionnel des élèves: Tentative de rapprochement des corpus écrit Grenouille et oral Frog. In C. Gunnarson-Largy \& E. Auriac-Slusarczyk (Eds.) Ecriture et réécritures chez les élèves (pp. 253-286). Paris: Académia.

Slusarczyk, B., Fiema, G., Auriel, A., \& Auriac-Slusarczyk, E. (2015). Étude de l'impact d'une introduction de la philosophie dans les curriculums au primaire et au collège sur l'intégrité cognitive. Recherche et Education, $14,123-145$.

Sternberg, R. J. (1999). Handbook of Creativity. London: Cambridge University Press.

Talbot, G. (1999). Phil et Sophie ou de l'Etre Humain. Quebec City: Le loup de Gouttière.

Thebault C. (2015). Une expérience d'atelier Philo \& Carto. Diotime, 65, 4-7.

Topping, K. J., \& Trickey, S. (2007). Collaborative philosophical enquiry for school children: Cognitive effects at 10-12 years. British Journal of Educational Psychology, 77, 271-288. https://doi.org/10.1348/000709906X105328

Torrance, E. P. (1966). The Torrance Tests of Creative Thinking-Norms-Technical Manual Research Edition-Verbal Tests, Forms A and B-Figural Tests, Forms A and B. Princeton, NJ: Personnel Press.

Tozzi, M. (2002). L'éveil de la pensée réflexive à l'école primaire. Montpellier: Publications du CRDP.

Ucus, S. (2017). Exploring creativity in social studies education for elementary grades: Teachers' opinions and interpretations. Journal of Education and Learning, 7(2), 111-125. https://doi.org/10.5539/jel.v7n2p111

Vergnioux, A. (2001). Le texte libre dans la pédagogie Freinet. Repères, 23, 151-168.

Villalba, E. (2008). On Creativity. Towards an Understanding of Creativity and its Measurements, JRC Scientific and Technological Reports, CRELL, EUR 23561. Luxembourg: Publications of the European Communities.

\section{Notes}

Note 1. The PreCPhi/Philosophemes Corpus (Auriac-Slusarczyk, Lebas-Fraczak, Blasco et al., 2012; Colletta \& Auriac-Slusarczyk, 2015) currently includes between 1,300 and 1,400 works of French-speaking pupils collected under controlled conditions (guidelines, material, working time, etc.). It is accessible to the scientific community through the following dedicated platform: http://philosophemes.univ-bpclermont.fr, hosted since 2011 by the Maison des Sciences de l'Homme in Clermont-Ferrand. 
Note 2. The COPHILEC project brings together the universities of Clermont Auvergne (France), Montreal (Quebec, Canada), Lorraine (France) and Grenoble-Alpes (France).

Note 3. Students are taught philosophy in the final year of lycée (17/18 years of age). Since 2011, philosophy teachers are allowed to raise pupils' awareness, in a free and exploratory manner, as early as the first year of lycée $(15 / 16$ years of age).

Note 4. This Corpus fits in with three other oral corpuses: Philosophèmes (Auriac-Slusarczyk \& Blasco-Dulbecco, 2013; Auriac-Slusarczyk \& Colletta, 2015), Grenouille (Gunnarson-Largy \& Auriac-Slusarczyk, 2013), and «C'est pas moi!» (Auriac-Slusarczyk, Foulquier, Baptiste, \& Slusarczyk, 2012), and is comprised of original handwritten documents, as with all the data on this dedicated platform. http://philosophemes.univ-bpclermont.fr

Note 5. For the first wave, images came from the illustrated cover of the journal Philosophie, n² July 2006, featuring a dog in an anthropomorphic position that evokes the disappearance of "man animal" boundaries. For the second wave, images came from the journal Sciences humaines, $\mathrm{n}^{\circ} 281$ May 2016, illustrating the theme of "nature and culture" through the frailty of a butterfly gently brushing the hand of a robot.

Note 6. La poupée parisienne, La liberté refusée, Le fumeur de rose, Le fumeur de bleu.

Note 7. Fisher's exact test was applied because conditions for the application of the Chi-squared test, typically used in this type of configuration, were not met (sample observations $<5$ ).

Note 8. All words in bold refer to pictorial elements from the artwork medium Chasseur d'étoiles.

\section{Copyrights}

Copyright for this article is retained by the author(s), with first publication rights granted to the journal.

This is an open-access article distributed under the terms and conditions of the Creative Commons Attribution license (http://creativecommons.org/licenses/by/4.0/). 